\title{
THE ROUTLEDGE COMPANION TO GLOBAL INTERNET HISTORIES
}

The Routledge Companion to Global Internet Histories brings together research on the diverse Internet histories that have evolved in different regions, language cultures and social contexts across the globe. While the Internet is now in its fifth decade, the understanding and formulation of its histories outside of an anglophone framework is still very much in its infancy. From Tunisia to Taiwan, this volume emphasizes the importance of understanding and formulating Internet histories outside the anglophone case studies and theoretical paradigms that have thus far dominated academic scholarship on Internet history. Interdisciplinary in scope, the collection offers a variety of historical lenses on the development of the Internet: as a new communication technology seen in the context of older technologies; as a new form of sociality read alongside previous technologically mediated means of relating; and as a new media "vehicle" for the communication of content.

Contributors: César Albarrán-Torres, Ilhem Allagui, Rajiv Aricat, Bunty Avieson, Niels Brügger, Anissa Daoudi, Stuart Davis, Charles Ess, Alisa Freedman, Martha Fuentes-Bautista, Ivo Furman, Shihui Gui, Fernando Gutiérrez, Tim Highfield, Larissa Hjorth, Arthur Hou-ming Huang, Dongwon Jo, Nicholas John, Rhys James Jones, Katarzyna KamińskaKorolczuk, Fumitoshi Kato, Barbara Kijewska, Kwang-Suk Lee, Li Shao Liang, Rich Ling, Sarah Logan, May O. Lwin, Hayes Mawindi Mabweazara, Robin Mansell, Teodor Mitew, Christopher Moore, Kana Ohashi, Elisa Oreglia, Sari Östman, Camille Paloque-Berges, Chitra Panchapakesan, Petri Saarikoski, Susana Salgado, Valérie Schafer, Nishant Shah, Jeremiah Spence, Christina Spurgeon, Joe Straubhaar, Jaakko Suominen, Joseph Suwamaru, Takanori Tamura, Benjamin G. Thierry, Endah Triastuti, Riikka Turtiainen, Andrew Whelan, Ling Yang, Lin Yi-Ren, Hu Yong, Haiqing Yu, Baohua Zhou.

Gerard Goggin is Professor of Media and Communications and ARC Future Fellow at the University of Sydney. He is widely published on mobile technologies and the Internet, including The Routledge Companion to Mobile Media (with Larissa Hjorth, 2014), New Technologies and the Media (2012), Global Mobile Media (2010), Internationalizing Internet Studies (with Mark McLelland, 2009), and Cell Phone Culture (2006).

Mark McLelland is Professor of Gender and Sexuality Studies at the University of Wollongong, and author or editor of ten books focusing on issues to do with the history of sexuality, popular culture, and new media in Japan and East Asia, most recently: Love, Sex and Democracy in Japan during the American Occupation (Palgrave Macmillan, 2012), and The Routledge Handbook of Sexuality Studies in East Asia, edited with Vera Mackie (Routledge, 2015). 
Review Copy - Not for Redistribution

Susena Salgado - Institute of Social Sciences - University of Lisbon - 06/03/2017 


\title{
THE ROUTLEDGE COMPANION TO GLOBAL INTERNET HISTORIES
}

\author{
Edited by \\ Gerard Goggin and \\ Mark McLelland
}

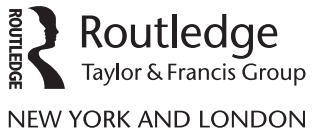


First published 2017

by Routledge

711 Third Avenue, New York, NY 10017

and by Routledge

2 Park Square, Milton Park, Abingdon, Oxon OX14 4RN

Routledge is an imprint of the Taylor \& Francis Group, an informa business

\section{(C) 2017 Taylor \& Francis}

The right of Gerard Goggin and Mark McLelland to be identified as the authors of this work has been asserted by them in accordance with sections 77 and 78 of the Copyright, Designs and Patents Act 1988.

All rights reserved. No part of this book may be reprinted or reproduced or utilized in any form or by any electronic, mechanical, or other means, now known or hereafter invented, including photocopying and recording, or in any information storage or retrieval system, without permission in writing from the publishers.

Trademark notice: Product or corporate names may be trademarks or registered trademarks, and are used only for identification and explanation without intent to infringe.

Library of Congress Cataloging in Publication Data Names: Goggin, Gerard, 1964- editor.

McLelland, Mark J., 1966- editor.

Title: The Routledge companion to global internet histories / edited by Gerard Goggin and Mark McLelland.

Other titles: Global internet histories

Description: New York: Routledge, Taylor \& Francis Group, 2017. Includes bibliographical references.

Identifiers: LCCN 2016038503| ISBN 9781138812161 (hbk) | ISBN 9781315748962 (ebk)

Subjects: LCSH: Internet-History. | TelecommunicationHistory-20th century. | Telecommunication-History-21st century. Classification: LCC TK5105.875.I57 R727 2017 | DDC 384.309-dc23

LC record available at https://lccn.loc.gov/2016038503

ISBN: 978-1-138-81216-1 (hbk)

ISBN: 978-1-315-74896-2 (ebk)

Typeset in Bembo

by Florence Production Ltd, Stoodleigh, Devon, UK 


\section{CONTENTS}

List of Figures and Tables

PART 1

Framing Concepts and Approaches

1 Imaginaries, Values, and Trajectories: A Critical Reflection on the Internet

ROBIN MANSELL

2 What's "Culture" Got to Do with It? A (Personal) Review of CATaC (Cultural Attitudes towards Technology and

Communication), 1998-2014

CHARLES ESS

3 The State of the Internets: Notes for a New Historiography of Technosociality

NISHANT SHAH

4 Probing a Nation's Web Domain: A New Approach to Web

History and a New Kind of Historical Source

NIELS BRÜGGER

PART 2

Rethinking Internet Evolution

5 From the Minitel to the Internet: The Path to Digital Literacy and Network Culture in France (1980s-1990s)

VALÉRIE SCHAFER AND BENJAMIN G. THIERRY 
6 The Emergence of the Internet Service Provider (ISP) Industry in Israel NICHOLAS JOHN

7 The Evolution of the Internet in Mexico (1986-2016) FERNANDO GUTIÉRREZ

8 The Social Shaping of the Brazilian Internet: Historicizing the Interactions Between States, Corporations, and NGOs in Information and Communication Technology Development and Diffusion

STUART DAVIS, JOE STRAUBHAAR, MARTHA FUENTES-BAUTISTA, AND JEREMIAH SPENCE

9 The History of the Internet in Estonia and Poland KATARZYNA KAMIŃSKA-KOROLCZUK AND BARBARA KIJEWSKA

\section{PART 3}

Early Computer Networks, Technology, and Culture

10 Mapping a French Internet Experience: A Decade of Unix Networks Cooperation (1983-1993)

CAMILLE PALOQUE-BERGES

11 Early Computer Networks in Japan, 1984-1994 MARK MCLELLAND

12 A Brief History of the Taiwanese Internet: The BBS Culture LI SHAO LIANG, LIN YI-REN, AND ARTHUR HOU-MING HUANG

13 H-mail and the Early Configuration of Online User Culture in Korea DONGWON JO

14 Hi! Turkiye and Turkish BBS and Digital Cultures IVO FURMAN

PART 4

Imagining Community via the Internet

15 Rethinking Arabic Linguistics: The History of the Internet in the Arabic-Speaking Region and the Rise of e-Arabic ANISSA DAOUDI

16 Social Imaginaries of the Internet in China HAIQING YU 
17 "Porn Shock for Dons" (and Other Stories from Welsh Pre-Web History)

RHYS JAMES JONES

18 Gross National Happiness and Facebook: Bhutan Localizes the Internet 269 BUNTY AVIESON

19 Land of the Disconnected: A History of the Internet in Papua New Guinea

SARAH LOGAN AND JOSEPH SUWAMARU

20 Mobile Communication in Myanmar

RICH LING, CHITRA PANCHAPAKESAN, RAJIV ARICAT, ELISA

OREGLIA, AND MAY O. LWIN

\section{PART 5}

Histories of Social Internets

21 Talking about Ourselves on the Japanese Digital Network

TAKANORI TAMURA

22 Histories of Blogging

TIM HIGHFIELD

23 Survival of the Most Flexible? National Social Media Services in Global Competition: The Finnish Case

JAAKKO SUOMINEN, PETRI SAARIKOSKI, RIIKKA TURTIAINEN, AND SARI ÖSTMAN

24 Towards the Social and Mobile: The Development of the

Mobile Internet in China and Japan

BAOHUA ZHOU, SHIHUI GUI, FUMITOSHI KATO,

KANA OHASHI, AND LARISSA HJORTH

25 Platforms, Practices, and Politics: A Snapshot of Networked Fan Communities in China

LING YANG

PART 6

Internets and New Media Forms

26 Online Advertising

CHRISTINA SPURGEON

27 Contexts, Prospects, and Contradictions: Histories of Internet-Based Digital Journalism Research in Africa HAYES MAWINDI MABWEAZARA 
28 Cellphone and Internet Novels: How Digital Literature Changed Print Books in Japan

ALISA FREEDMAN

29 Where the Stakes are Higher: Transnational Labor and Digital Gambling Media

CÉSAR ALBARRÁN-TORRES

30 The Emergence of Vernacular Digital Music Cultures ANDREW WHELAN

31 Histories of Internet Games and Play: Space, Technique, and Modality

TEODOR MITEW AND CHRISTOPHER MOORE

PART 7

Publics, Politics, and Digital Societies

32 Digital Media and Socio-Political Change in the Arab Region

33 Indonesia's Internet Blueprint: Shifting Experience in Media Culture

ENDAH TRIASTUTI

34 Histories of the Internet and Political Communication in

Lusophone Africa

SUSANA SALGADO

35 Amplifying Cyberactions: A Short History of e-Resistance in South Korea

KWANG-SUK LEE

36 From Yulun (Public Opinion) to Yuqing (Public Intelligence):

Their History and Practice in China's Information Management

HU YONG 


\section{FIGURES AND TABLES}

\section{Figures}

5.1 An Antiope page (created around 1980 by Bernard Marti) 79

5.2 Minitel 1 (France, 1982) 81

$\begin{array}{lll}7.1 & \text { The first Mexican connections to BITNET } & 106\end{array}$

$\begin{array}{lll}7.2 & \text { Growth of domains . } \mathrm{mx} & 108\end{array}$

$\begin{array}{lll}7.3 & \text { Internet users in Mexico } & 112\end{array}$

$\begin{array}{lll}\text { 7.4 Reasons limiting Internet use in Mexico } & 112\end{array}$

$\begin{array}{lll}\text { 7.5 General distribution of Internet users by age } & 113\end{array}$

$\begin{array}{lll}\text { 7.6 Internet penetration by socio-economic level, 2009-2013 } & 113\end{array}$

7.7 Devices of Internet users in Mexico in percent 114

7.8 Information production by Internet users in Mexico, 2010-2013 115

7.9 Cultural practices of Internet users in Mexico, 2011-2013 116

7.10 Following the presidential campaigns on the Internet, $2012 \quad 117$

7.11 Influence of the Internet on voting intentions in the 2012 presidential
elections

$\begin{array}{lll}\text { 7.12 Platforms most commonly used to follow the } 2012 \text { presidential campaigns } & 118\end{array}$

7.13 Internet penetration in Mexico according to the OECD (2014) 119

9.1 Individuals: Internet use in the EU in 2014 in percent 140

9.2 E-government activities of individuals via websites (last 12 months) in the EU, Estonia, and Poland in 2014 in percent 143

9.3 Households with broadband access in the EU, Estonia, and Poland in 2014 in percent 145

9.4 Individuals: Internet use in Estonia and Poland in 2004-2014 in percent 146

10.1 Two extracts of an 18 March 1983 Usenet message, entitled "Europe map" 163

14.1 Bell modem 103 from time.com 211

14.2 An Altair $8800 \quad 211$

14.3 A BBS terminal system that combines a Commodore 64 with a compatible acoustic coupler to connect to a BBS 211

14.4 Global organization of Fidonet through nodes in other zones 211

$\begin{array}{ll}14.5 & \text { Artwork from the Turkish Demoscene } \\ 14.6 & 217\end{array}$

14.6 Artwork from the Turkish Demoscene 217

$\begin{array}{ll}\text { 14.7 Artwork from the Turkish Demoscene } & 217\end{array}$

14.8 Artwork from the Turkish Demoscene 217

$\begin{array}{ll}14.9 & \text { Welcome page for ESS BBS }\end{array}$

18.1 ICT/telecommunication subscribers: actual and as percentage of population 272

$\begin{array}{ll}18.2 \text { Total subscribers/percent of population } & 272\end{array}$ 
FIGURES AND TABLES

$\begin{array}{lll}21.1 & \text { Students writing or reading about themselves on CMC } & 314\end{array}$

$\begin{array}{lll}21.2 & \text { Network map of frequently concurrent words on FLADY } & 317\end{array}$

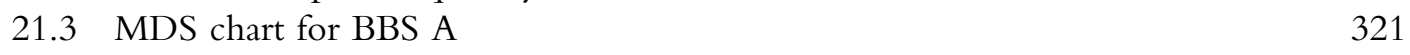

21.4 MDS chart for BBS B 322

21.5 Network map of Misao Redwolf 324

21.6 Network map of @ tatangarani 325

21.7 Network map of speeches in front of the prime minister's residence 326

$\begin{array}{lll}21.8 & \text { Comparison of three texts } & 327\end{array}$

23.1 Registered users according to IRC-Galleria's own information 347

23.2 Weekly visits to the IRC-Galleria sites according to TNS-Metrix 348

23.3 Hits of IRC-Galleria in the Sanoma newspaper archive 349

$\begin{array}{lll}24.1 & \text { A Weibo screenshot } & 360\end{array}$

$\begin{array}{ll}24.2 \text { A family WeChat group } & 360\end{array}$

24.3 A WeChat "Moment" screenshot 362

24.4 Decomail (NTT docomo) 364

24.5 Use of popular social media (by age groups) 365

24.6 Chat with rabbit stamps on LINE 366

25.1 A screenshot taken from the homepage of Li Yi Bar, $2015 \quad 378$

$\begin{array}{lll}28.1 & \text { Unicode standard } 3.0 \text { emoji } & 414\end{array}$

28.2 Book cover of Deep Love: Ayu's Story manga, Vol. 1

28.3 Screenshot from the Train Man Internet novel 419

31.1 A screenshot of The Pirate Bay PC games offering 456

32.1 Evolution of Internet penetration rate (percent) in selected Arab countries 465

32.2 Percentages of households with Internet and computers (2013) 466

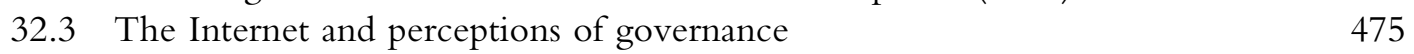

\section{Tables}

9.1 Internet activities in Estonia and Poland in 2014 in percent

12.1 Development of TANet (Taiwan Academic Network) and TANet BBS in Taiwan

15.1 Romanizing Arabic with number substitution 233

32.1 Categories of the top 25 visited websites in selected Arab countries 473 


\section{CONTRIBUTORS}

César Albarrán-Torres is a lecturer in Media and Communication at Swinburne University of Technology in Melbourne, Australia. He has been widely published in academic and non-academic publications as a film and literary critic, author, and translator. His current research focuses on what he calls "gamble-play media", hybrid platforms where gambling and digital interactive media intersect.

Ilhem Allagui is Associate Professor-in-residence in the Journalism program at Northwestern University in Qatar. She earned her Ph.D. (2006) and MSc (2000) in Communication from the University of Montreal, Canada. Her research interests include the social integration of new media, Internet studies, Internet adoption and development in the MENA region, digital transformations and social empowerment in the MENA region, the Arab cultural industries, as well as entrepreneurship, advertising, and public relations practices in the MENA region. Dr. Allagui joined the World Internet Project network in 2007, and launched the Emirates Internet Project (2007-2014) that was awarded the National Research Foundation grant (UAE) in 2009. The results of this research are discussed in a forthcoming book, Technology and the Stresses to a National Community: The Case of the United Arab Emirates. Ilhem Allagui serves on the editorial board of the International Journal of Communication (USC).

Rajiv Aricat is a research associate in Wee Kim Wee School of Communication \& Information, Nanyang Technological University, Singapore. For his Ph.D., he studied the impact of mobile phones on South Asian migrant workers' acculturation to Singapore. During 2014-2015, he was part of a research project that investigated the adoption, usage, and impact of mobile phones in Myanmar. Originally from Kerala, India, Rajiv has an M.Phil. in Semiotics (Jawaharlal Nehru University, New Delhi) and a Master's in Communication \& Journalism (University of Kerala).

Bunty Avieson is a lecturer in the Department of Media and Communications at the University of Sydney, where she teaches news writing. A former journalist, she has also published three novels, a novella, and two memoirs. The most recent, The Dragon's Voice: How Modern Media Found Bhutan, was about the year she spent in Bhutan as a media consultant funded by the UN.

Niels Brügger is Professor of Internet Studies and Digital Humanities at Aarhus University, Denmark; Head of the Centre for Internet Studies, and of NetLab. His research interests are Web historiography, Web archiving, and digital humanities. Recent books include 


\section{NOTES ON CONTRIBUTORS}

Web History (ed., Peter Lang, 2010) and Histories of Public Service Broadcasters on the Web (co-ed. with M. Burns, Peter Lang, 2012), and he is editing a special issue of New Media $\mathcal{E}$ Society about the first 25 years of the Web's history, as well as the following forthcoming books: The Web as History: Using Web Archives to Understand the Past and the Present (coed. with R. Schroeder, UCL Press, 2016), Web 25: Histories from the First 25 Years of the World Wide Web (Peter Lang, 2016), and the Sage Handbook of Web History (co-ed. with M. Anderson and I. Milligan, Sage, 2017). Finally, he is preparing the monograph The Archived Web: Doing History in the Digital Age (MIT Press, 2017).

Anissa Daoudi is a lecturer in Arabic and Translation Studies. She is Head of Arabic Section and Specialist for the Translation Studies (Arabic-English-Arabic) program. She recently won the Leverhulme Fellowship for her project on "Narrating and Translating Sexual Violence in Algeria in the 1990s," which is in the areas of translation studies, memory and narrativity. She is the author of Cultural and Linguistic Encounters: Arab EFL Learners Encoding and Decoding Idioms (2012) and other edited books and articles in linguistics and discourse analysis.

Stuart Davis is Assistant Professor of Communication and Director of the graduate program in Latin American Communication and Media Studies at Texas A\&M-International University. He has articles published or forthcoming in Communication Theory, Digital Journalism, International Journal of Communication, and Journalism Practice, as well as edited collections including Civic Media: Technology, Design, Practice (MIT Press), Inequity in the Technopolis: Race, Class, Gender, and the Digital Divide in Austin, Texas (University of Texas Press), and Protests in the Information Age: Social Movements, Digital Practices, and Surveillance (Routledge). In 2013, he was a William J. Fulbright Scholar in the Department of Sociology at the Federal University of Rio de Janeiro. In 2015, he was a post-doctoral fellow in the graduate program in Media and Technology, Department of Social Communication, State University of São Paulo.

Charles Ess works at the intersections of philosophy, computing, applied ethics, comparative philosophy, and media studies, with particular focus on research ethics, digital religion, and virtue ethics in media and communication, specifically social robots. He serves as a research ethics consultant for the VOX-Pol Network of Excellence and the H2020 ICTproject HUMANE. His recent guest positions include Aarhus University (2009-2012), University of Vienna (2013-2014), University Institute of Lisbon (ISCTE-IUL-2015, 2016), and the Vienna University of Economics and Business (2016).

Alisa Freedman is Associate Professor of Japanese Literature and Film at the University of Oregon. Her books include Tokyo in Transit: Japanese Culture on the Rails and Road (Stanford University Press, 2010), an annotated translation of Kawabata Yasunari's The Scarlet Gang of Asakusa (University of California Press, 2005), and the co-edited volumes Modern Girls on the Go: Gender, Mobility, and Labor in Japan (Stanford University Press, 2013) and Introducing Japanese Popular Culture (forthcoming from Routledge). She has published articles and edited special journal issues on Japanese modernism, Tokyo studies, youth culture, gender, television, humor as social critique, teaching pedagogies, and intersections of literature and digital media, along with translations of Japanese literature. She is Editor-in-Chief of the US-Japan Women's Journal. 
Martha Fuentes-Bautista is Senior Lecturer and Director of Engaged Research \& Learning, in the Department of Communication at the University of Massachusetts, Amherst. Fuentes-Bautista's research focuses on social stratification of digital media systems, and the role of advocacy networks, media activism, and media reform movements in shaping media democracy and digital inclusion efforts in the U.S. and ILatin America. Her areas of interest include: media technologies and social inequality; community media policy; media reform and justice movements; community broadband and digital inclusion; empowerment evaluation and participatory action research.

Ivo Furman is a post-doctoral researcher at the Turkish Science and Technology Foundation (TUBITAK) and part-time lecturer at the Faculty of Media and Communications at Istanbul Bilgi University. He completed his Ph.D. in Sociology at Goldsmiths College, University of London in 2015. Furman is currently part of a research project that aims to build an open access Twitter research platform for social science researchers interested in social media analytics. The system, Bilgi-TCAT, will be fully operational by the end of 2016. Furman also teaches a course in digital methods, wherein students are taught how to collect, clean, and visualize data from social media platforms such as Twitter, Instagram, and Facebook. He will also start teaching a data journalism course next year. Furman's research has been supported by the Istanbul Bilgi University, Freedom House, European Corporation in Science and Technology (COST) Goldsmiths College, the Arts and Humanities Research Council (AHRC), Goethe Institut in London and Berlin, the Central Research Fund, the British Sociological Association, Administratia Fondului Cultural National (AFCN), the Museum of Contemporary Art in Bucharest (MNAC), British Sociological Association, and the British Institute in Ankara (BIAA). Furman's current research interests include digital methods focusing on Twitter and Instagram, social network analysis, data visualization, digital sociology, and data journalism.

Gerard Goggin is Professor of Media and Communications and ARC Future Fellow at the University of Sydney. He is widely published on mobile technologies and the Internet, including the books Locative Media (with Rowan Wilken, 2015), The Routledge Companion to Mobile Media (with Larissa Hjorth, 2014), New Technologies and the Media (2012), Global Mobile Media (2010), Internationalizing Internet Studies (with Mark McLelland, 2009), and Cell Phone Culture (2006). Gerard has a longstanding interest in disability, media, and technology, with key volumes being The Routledge Companion to Disability and Media (with Katie Ellis and Beth Haller, 2017), Disability and the Media (with Katie Ellis, 2015), and Digital Disability (with Christopher Newell, 2003).

Shihui Gui was born in Shanghai in the 1990s and received her BA from Peking University in 2014, majoring in English Literature. She is expected to receive her MA in New Media Communication from Fudan University by June 2016. Due to her strong interest in social media, she chose The Influence of WeChat on Intergenerational Relationships in China as her graduation thesis. Shihui will start her career at IBM China and will continue to focus on the TMT industry.

Fernando Gutiérrez is Dean of the School of Social Sciences and Humanities at the Monterrey Institute of Technology and Higher Education (Santa Fe Campus). He earned a Master's degree in Information Technologies, and a Ph.D. in Design and Data Visualization from the Metropolitan Autonomous University (UAM). He also serves as a member of the board 
of directors of the Media Ecology Association, is Head of the World Internet Project in Mexico, and a member of the Mexican Academy of Communication. His research focuses on "The Exploration of Flows to Predict Shapes: A Constructal Approach to Understand the New Media Ecology in the Digital Age." He was the coordinator of the Alfaomega collection "Ciudadan@ de Internet" (Internet Citizen) and author and associate editor of the following Spanish titles: La Comprensión de los medios en la era digital; Internet como herramienta para la investigación; Explorando el ciberperiodismo Iberoamericano; .com probado Modelos exitosos de Internet en México; Internet: el Medio Inteligente. Fernando has received the Louis Forsdale Award, 2015 from the Media Ecology Association; the National Research Award, 2012 from the Federation of Private Mexican Institutions of Higher Education (FIMPES); and the Gunther Saupe Award, 2009 from the Communication \& Marketing Industry Confederation (CICOM), among other honors.

Tim Highfield is Vice-Chancellor's Research Fellow in the Digital Media Research Centre at Queensland University of Technology. He is the author of Social Media and Everyday Politics (Polity, 2016). His current fellowship project is "Visual Cultures of Social Media", and his research draws together social media, popular culture, politics, activism, Internet cultures, and more. Full details are available at timhighfield.net.

Larissa Hjorth, Professor, is an artist and digital ethnographer in the School of Media \& Communication, RMIT University. She has co-edited The Routledge Handbook to New Media in Asia (with O. Khoo), The Routledge Companion to Mobile Media (with G. Goggin), Gaming Cultures and Place (with D. Chan), Mobile Technologies (with G. Goggin), Art in Asia-Pacific (with N. King and M. Kataoka), Mobile Media Practices, Presence and Politics: The Challenge of Being Seamlessly Mobile (with K. Cumiskey), and Studying Mobile Media (with I. Richardson and J. Burgess). Hjorth is currently first CI on two Australian Research Council (ARC) grants: one Linkage with Intel, Locating the Mobile, on locative media in Japan, China, and Australia (with S. Pink and H. Horst) (LP130100848); one Discovery (with I. Richardson), Games of Being Mobile, on mobile gaming in Australian everyday life (DP140104295). Since 2000, Hjorth has been researching the gendered and socio-cultural dimensions of mobile media and play cultures in the Asia-Pacific. These studies are outlined in her books Mobile Media in the Asia-Pacific (Routledge, 2009), Games \& Gaming (Berg, 2010), Online@AsiaPacific (with Arnold, Routledge, 2013), Understanding Social Media (with Hinton, Sage, 2013), Gaming in Social, Locative and Mobile Media (with Richardson, Palgrave, 2014), Haunting Hands (with K. Cumiskey, Oxford University Press, 2016), Digital Ethnography (with Pink, Horst, Postill, Lewis, and Tacchi (Sage, 2016), and Screen Ecologies (with Pink, Sharp, and Williams, MIT Press, 2016).

Arthur Hou-ming Huang is Associate Professor of the Department of Sociology, National Chengchi University, Taiwan. He has been a heavy user of the Internet, and has engaged in studies of the Internet culture of Taiwan since 1994. He is currently conducting a study on Ingress from the viewpoint of phenomenology of technology. He is now on the editorial boards of the Journal of Cyber Culture and Information Society, and Societas: A Journal of Philosophical Study of Public Affairs.

Dongwon Jo is a post-doctoral researcher at Flinders University, Adelaide, Australia in 2016. He has recently researched on socio-cultural histories of information technologies in Korea and East Asia, particularly on the history of electronics markets, (micro)computers, 
$\mathrm{BBS}$, the Internet, and their users. His present projects include a comparative history of the the Internet and Videotex in France and Korea; a comparative archiving project for microcomputer users' experiences and memories in Australia and Korea; and a study on the practices of microcomputer cloning and circulation of that knowledge, parts, and products across the electronics markets in the early 1980s in Japan, Taiwan, Hong Kong, and Korea.

Nicholas John is Assistant Professor at the Department of Communication and Journalism, the Hebrew University of Jerusalem, Israel. He has written extensively about the arrival of the Internet to Israel and its diffusion there. Other research projects include a large study of sharing in the digital age, and pioneering work on Facebook unfriending, especially in relation to political disagreement. Find more at http://nicholasjohn.huji.ac.il.

Rhys James Jones is Senior Lecturer in Digital Media in the Department of Media and Communication, Swansea University. He researches Wales and the Welsh language in contemporary and historical online contexts, and is currently investigating the use of Welsh on social media by political parties during election campaigns.

Katarzyna Kamińska-Korolczuk, Ph.D., is a lecturer at the Political Science Institute at the Faculty of Social Science at the University of Gdańsk, Poland. Her main area of research is political and party systems, including relations between political actors and the media. She is especially interested in the party and media systems in Estonia and Latvia. From 2012 to 2016, she was the Deputy Director of the Institute of Political Science, University of Gdańsk, where she was responsible for raising the quality of teaching and modernizing the study programs, and she also co-created a new field of study: diplomacy. She is the scientific editor of four books, and the author of many book chapters and scientific articles.

Fumitoshi Kato, Ph.D. Communication, is currently working as a professor at the Faculty of Environment and Information Studies, Keio University, Japan. His research interests include communication theory, media studies, socio-cultural impacts of new technologies, and qualitative research methods. He is especially interested in the use of camera phones in the context of community development. For the past few years, he has been conducting field research in various local communities in Japan, with a primary focus on the notion of "mobile learning".

Barbara Kijewska is Assistant Professor at the Institute of Political Science, University of Gdańsk (Poland). She has been involved in international projects in the societal aspects of energy technology. Her research has been mainly concerned with issues of gender, especially women's political activity and mass media research. She is the author of numerous papers and communications. She is an expert of the Polish Ecological Club and member of the WAGA Association promoting equality between women and men.

Kwang-Suk Lee is Director of IT Convergence Policy Research Institute and Assistant Professor in the Graduate School of Public Policy and Information Technology at Seoul National University of Science and Technology. Lee earned his Ph.D. in the Radio-TVFilm Department of the University of Texas at Austin. He has been an Australian Research Council (ARC) post-doctoral research fellow. His recent publications include the following 
books: Aesthetic Notes from the Edge (Seoul, 2016), New Art Activism (Seoul, 2015), Digital Barbarism (Seoul, 2014), IT Development in Korea: A Broadband Nirvana (London: Routledge, 2012), and The Art and Cultural Politics of Cyber Avant-Gardes (Seoul, 2010).

Shao Liang Li is Master of the Department of Sociology, National Chengchi University, Taiwan. He is interested in science and technology studies, the sociology of technology, and cyber culture and the information society. He is currently working in the digital marketing industry.

Rich Ling is the Shaw Foundation Professor of Media Technology, Wee Kim Wee School of Communication and Information, Nanyang Technological University, Singapore. His work focuses on the social consequences of mobile communication.

Sarah Logan is an honorary research fellow in the Department of Government and International Relations at the University of Sydney. She was previously the inaugural digital politics research fellow in the Department of State, Society and Governance in Melanesia at the Australian National University. Her research interests include the political and social impact of the Internet on emerging democracies, and the impact of the Internet on international politics.

May O. Lwin is Associate Professor in the Wee Kim Wee School of Communication and Information, Nanyang Technological University. Concurrently, Lwin serves as the Associate Dean at NTU's College of Humanities, Arts, and Social Sciences. Lwin specializes in strategic and health communication. Her projects involve the assessment and development of digital media systems to tackle societal and health concerns. In Myanmar, she is currently involved in projects studying how technology can improve public health. She has published widely in journals such as the Journal of Communication, the Journal of Consumer Research, and the Journal of Adolescence. Email contact for Lwin: mailto:tmaylwin@ntu.edu.sg.

Hayes Mawindi Mabweazara, Ph.D., is Senior Lecturer in Journalism Studies at Falmouth University, UK. He is Associate Editor for African Journalism Studies (Routledge) and edits the journal's Special Annual Issue titled African Digital Media Review. Mabweazara serves on the editorial boards of Digital Journalism (Routledge), Journalism Practice (Routledge) and the Journal of Alternative and Community Media (Griffiths University). He edited Digital Technologies and the Evolving African Newsroom (Routledge, 2015), as well as co-edited Online Journalism in Africa (Routledge, 2014). He also guest-edited a special issue of Journalism: Theory, Practice \& Criticism (Sage, 2011), titled "New Media and Journalism Practice in Africa: An Agenda for Research" (with Prof. Chis Atton). Mabweazara is currently working on a monograph, titled Africa's Mainstream Press in the Digital Era, due for publication by Palgrave Macmillan.

Robin Mansell is Professor of New Media and the Internet in the Department of Media and Communications, London School of Economics and Political Science. She has been Head of the LSE Media and Communications Department, President of IAMCR, and Scientific Chair of EUROCPR. She is the author of numerous academic papers and books including Imagining the Internet: Communication, Innovation and Governance (Oxford University Press, 2012). 
Mark McLelland is Professor of Gender and Sexuality Studies at the University of Wollongong, and author or editor of ten books focusing on issues to do with the history of sexuality, popular culture, and new media in Japan and East Asia, most recently Love, Sex and Democracy in Japan during the American Occupation (Palgrave Macmillan, 2012), and The Routledge Handbook of Sexuality Studies in East Asia, edited with Vera Mackie (Routledge, 2015).

Teodor Mitew specializes in actor network theory and ambient socio-digital systems. His current research includes the implications of the Internet of Things for sociability and memory, maker communities, and object-oriented ontology. His recent research explores the application of actor network theory to the study of mobile socio-technical assemblages. He is a senior lecturer in Digital Media and Communication at the University of Wollongong, Australia.

Christopher Moore is a lecturer in Digital Communication and Media Studies at the University of Wollongong, Australia. His research in game studies examines the affective dimensions of multiplayer and first-person experiences. He is currently focused on the appropriation of game engines and virtual reality interfaces for archival curation and knowledge production in open and collaboratively assembled spaces. Most recently coediting the journal of Persona Studies, his research in the digital humanities explores the role of digital objects in the presentation and personal surveillance of the public self online.

Kana Ohashi is a doctoral student at the Graduate School of Media and Governance, Keio University, Japan. She graduated from Keio University and completed a documentary filmmaking program at Met Film School. Her research interests are mobilities studies, sociology of families, and video ethnography. She is especially interested in how people experience migration and how they maintain long-distance relationships with their family members. Currently, she is making ethnographic videos on transnational lives in Japan.

Elisa Oreglia, Ph.D., UC Berkeley, is a lecturer in Global Digital Media at the Centre for Media Studies, SOAS, University of London. She studies the appropriation of digital media among marginal users in China and Myanmar, with a particular focus on local knowledge production and information-sharing practices in markets.

Sari Östman, Ph.D., Researcher, Digital Culture, University of Turku. Her Ph.D. study (defended in 2015) analyzed the appropriation of life-publishing, the phenomena and a concept which unites all the practices and motives for telling about ourselves and our lives online. She has published multiple scholarly articles about life-publishing and research ethics.

Camille Paloque-Berges holds a Ph.D. in Information and Communication sciences with a thesis on the cultural history of Internet folklore. She is the author of Poétique des Codes sur les Réseaux Informatiques (2009) and co-editor of Histoires et Cultures du Libre (with C. Masutti, 2013). Today, she is a research engineer at the lab for History of Techno-Sciences (HT2S) at the Conservatoire National des Arts et Métiers in Paris and an associated researcher at the "Trajectoires numériques" cluster of the Communication Science Institute of CNRS (ISCC). 


\section{NOTES ON CONTRIBUTORS}

Chitra Panchapakesan is a doctoral candidate in the Wee Kim Wee School of Communication and Information at Nanyang Technological University, Singapore. Her research interest focuses on mobile communication, media effects, gender roles, and civic engagement.

Petri Saarikoski, Ph.D., Docent, University Lecturer, Department of Digital Culture, University of Turku. Saarikoski has studied the history of computer hobbyism and home computer culture in Finland.

Susana Salgado, Ph.D., 2007, University of Lisbon, is a researcher and Professor of Political Communication and Media and Politics at the Institute of Social Sciences, University of Lisbon, Portugal. Her research work is currently sponsored by the Portuguese Foundation for Science and Technology (IF/01451/2014/CP1239/CT0004).

Valérie Schafer is a researcher at the French National Center for Scientific Research (Institute for Communication Sciences). She specializes in the history of computing and telecommunications. Her current research deals with the Internet and Web history in France and Europe.

Nishant Shah is the co-founder of the Centre for Internet \& Society, Bangalore, India, a guest professor of Culture and Aesthetics of Digital Media (ICAM) at Leuphana University, Lüneburg, Germany, and the Dean-Research at ArtEZ University of the Arts, in the Netherlands. His work is at the intersections of digital technologies, social justice, and new modes of knowledge production and intervention making.

Jeremiah P. Spence, Ph.D., is Assistant Professor of International and Global Communications in the Department of Media \& Communication at the Erasmus University in Rotterdam, Netherlands. Spence completed his doctorate in 2015 in the Department of Radio, TV \& Film at the University of Texas at Austin with a dissertation on the theme of TV audience research in Brazil from 2004 to 2014, with significant findings regarding the theorization of cultural proximity in the field of international media flows. Spence is currently researching the media consumption habits of recent migrants and refugees within the European Union countries, with a specific focus on questions related to acculturation.

Christina Spurgeon lectures in Journalism, Media and Communication in the Creative Industries Faculty at the Queensland University of Technology, Brisbane, Australia, and is an active media studies researcher and postgraduate supervisor. Christina serves on the editorial board of Media International Australia and edits 3CMedia: Journal of Community, Citizens, and Third Sector Media. Her book, Advertising and New Media, was published by Routledge in 2008.

Joe Straubhaar is the Amon G. Carter Sr. Centennial Professor of Communication in the Radio-Television-Film Department, and Director of the Latino and Latin American Media Studies program at the University of Texas at Austin. His current research concerns the globalization of television and new media, the BRICs, television in Brazil, the digital divide in Brazil and Texas, media and migration, and ICTs and development in Brazil and Texas. He is co-author of Television in Latin America (BFI, 2013), the author of World Television: From Global to Local (Sage Publications, 2007), and editor of Inequity 
in the Technopolis: Race, Class, Gender and the Digital Divide in Austin (University of Texas Press, 2011), and numerous journal articles and conference papers on these topics.

Jaakko Suominen, Ph.D., Professor of Digital Culture at University of Turku. With a focus on cultural history of media and information technologies, Suominen has studied computers and popular media, the Internet, social media, digital games, and theoretical and methodological aspects of the study of digital culture. He has led several multidisciplinary research projects, funded by the Academy of Finland, Tekes, companies, and municipal bodies, and has over 100 scholarly publications. Currently, Suominen leads the Mindscapes24 research project (Academy of Finland funding \#293460), where the digital culture research group is studying the history of social media in Finland.

Joseph Suwamaru earned his $\mathrm{Ph} . \mathrm{D}$. for research on aspects of mobile phone usage in socio-economic development in Papua New Guinea (PNG). Prior to completing his Ph.D., he was the Executive Director of the Engineering Department within the former ICT regulator in PNG, PANGTEL. He also served as Vice Chairman of the Asia Pacific Telecommunity Study Groups. On completing his Ph.D., Dr. Suwamaru became a senior lecturer within the Department of Information Systems at the Divine Word University in Madang, PNG. He currently sits on the board of directors of a new state-owned enterprise in PNG, DATACO, tasked with rolling out terrestrial and undersea submarine fiber-optic cables across PNG and Melanesia.

Takanori Tamura is a lecturer at $\mathrm{H}$ sei University in Tokyo. He studies human interaction in computer mediated communication (CMC). Starting from studies of a pre-internet domestic networking system in Japan, he is interested in the self presentation and interaction of people via CMC based on a narrative approach. He has written on religion, privacy and social movements' use of CMC. He is the author, along with Tamura Daiyu, of "Reflexive Self Identification of Internet Users and the Authority of Soka Gakkai: Analysis of Discourse in Japanese BBS, Ni-Channeru", pp. 173-195 in Japanese Religions on the Internet: Innovation, Representation, and Authority, New York, Routledge, 2011.

Benjamin G. Thierry is Assistant Professor at Paris-Sorbonne University. He teaches media and technical history. He is a specialist in interactivity and computer interfaces from the 1960s. Recent publications include Le Minitel, l'Enfance Numérique de la France (The Minitel, the French Digital Childhood) (Nuvis, 2012), co-authored with Valérie Schafer.

Endah Triastuti is a researcher at the Communication Research Centre and a lecturer in Media Studies at the University of Indonesia. Her interests are in convergent media practices, including the anthropology of the media. Her current work is designing researchbased policy to establish in broadband villages in disadvantaged areas throughout Indonesia for the Ministry of Telecommunications and ICT.

Riikka Turtiainen, Ph.D., University Lecturer, Digital Culture, University of Turku. Her doctoral thesis (defended in 2012) illustrated the multiplicity of the uses of digital technologies and services including games in the context of media sport. She has published multiple scholarly articles about digital media sports and online cultures, and specializes in online research ethics. 


\section{NOTES ON CONTRIBUTORS}

Andrew Whelan is a sociology lecturer at the University of Wollongong. He has written previously about "extreme" music and underground electronic music subcultures, sampling aesthetics and canonical samples, the cultural politics of digital media, Australian media regulation policy, peer-to-peer file-sharing, and online interaction about music. His work has been published in First Monday, Sociological Research Online, Sites, and the recent edited volumes Music at the Extremes (2015) and Researching Music Censorship (2016). He is coeditor of Networked Music Cultures (2016).

Ling Yang is Assistant Professor of Chinese at Xiamen University, P.R. China. She is the author of Entertaining the Transitional Era: Super Girl Fandom and the Consumption of Popular Culture (China Social Sciences Press, 2012) and the co-editor of Fan Cultures: A Reader (Peking University Press, 2009). She has published on Chinese fan culture, popular culture, and Web literature in both English and Chinese.

Lin Yi-Ren is a doctoral student at the Graduate School of Interdisciplinary Information Studies, University of Tokyo. Originally trained in economics and sociology, he is now focusing on media studies with a sociological perspective, and is currently writing a Ph.D. dissertation on Taiwanese Internet users, their roles in the recent political power shift in Taiwan, and how they help form an emotional public culture. For more information, please visit http://villagersociety.info.

Hu Yong is Professor of Journalism and Communication at Peking University's School of Journalism and Communication. Prior to joining the academy, Professor $\mathrm{Hu}$ was a journalist, social activist, entrepreneur, and translator. He is a founding director of the Communication Association of China (CAC) and China New Media Communication Association (CNMCA). He is a member of the China Information Economics Society (CIES), and the World Economic Forum Global Agenda Council on Social Media, as well as the steering committee of the Chinese Internet Research Conference (CIRC). He is the author of 13 books, including Network Politics: Contemporary Chinese Society and Media Options for Action (National School of Administration Press, 2014).

Haiqing Yu is Senior Lecturer in Contemporary Chinese Media and Culture at the University of New South Wales, Australia. Haiqing is the author of Sex in China, with Elaine Jeffreys (Polity, 2015) and Media and Cultural Transformation in China (Routledge, 2009). Her research covers two broad disciplines: media studies and cultural/sociological studies, focusing on the political economy of digital media and communication in China, contemporary Chinese youth culture and sexuality, and social movements. Haiqing has published widely in these areas in refereed academic journals.

Baohua Zhou is a professor and Assistant Dean at the School of Journalism, Fudan University. $\mathrm{He}$ is Director of the New Media Communication Master's program and Associate Director of the Media and Public Opinion Research Centre at Fudan University. He was a visiting scholar at the University of Pennsylvania. He was awarded the Changiiang Young Scholar by the Ministry of Education of China. His research focuses on digital media, media effects, and public opinion. His current research projects include social differentiation, media use, and citizenship engagement in China; ICTs and migrants workers; social media and journalism; and public opinion on social media, among others. His research has been published in the Asian Journal of Communication, the Chinese Journal of Communication, Communication \& Society, and various communication journals in China. 


\section{ACKNOWLEDGEMENTS}

We thank the Australian Research Council (ARC) for the award of a Discovery grant, Internet History in Australia and the Asia-Pacific (DP1092878), of which this volume is a key output. We are very grateful to Emily van der Nagel for her excellent editorial assistance in the preparation of the manuscript. It has been our pleasure to once again work with the talented and consummate publishing professionals at Routledge. Special thanks to Erica Wetter for her commissioning of the project and thoughtful feedback, and also to Simon Jacobs and Mia Moran for all their help. 
Review Copy - Not for Redistribution

Susena Salgado - Institute of Social Sciences - University of Lisbon - 06/03/2017 


\author{
34 \\ HISTORIES \\ OF THE INTERNET \\ AND POLITICAL \\ COMMUNICATION IN \\ LUSOPHONE AFRICA \\ Susana Salgado
}

\title{
Introduction
}

The Portuguese-speaking African countries offer particularly interesting case studies when the objective is to examine the political influence of the Internet. ${ }^{1}$ Angola, Cape Verde, Mozambique, and Sao Tome and Principe ${ }^{2}$ share the same language and a similar historical background of nearly five centuries of Portuguese colonization, and although with very different degrees of success, these countries are also commonly considered new democracies. In the early 1990s, the third wave of democratization (Huntington 1991), which had started in 1974 with the Carnation Revolution in Portugal, spread to Africa, and several sub-Saharan African countries initiated democratic reforms, mainly by adopting new constitutions, multiparty regimes, and elections as the means to select rulers. These four countries also share the particular feature of having started their democratization processes simultaneously with the worldwide expansion of the Internet.

The development of the Internet can be addressed from many different angles; for example, the history of the medium itself includes not only the elements that have affected its development, but also the implications of its historical evolution in different contexts. Different regions of the world, different areas of society, and different social and age groups are likely to induce different experiences, adaptations, perceptions, histories, and therefore outline different understandings and paradigms of the Internet's evolution and its effects. In addition, histories of the individuals' use of the Internet and their lives intersect and contribute to building not only the history of a country, but also the history of the Internet.

These countries' histories represent valuable illustrations of different Internet histories and of different Internet development paces. The Internet has influenced communicative practices in general, and political communication in particular, by adding different dimensions to power discourses and facilitating collective action, for instance. Particularly in developing countries, the Internet has the potential to enhance active citizenship and promote political participation by providing citizens with alternative ways to demand more freedom and social justice. 


\author{
HISTORIES OF THE INTERNET IN LUSOPHONE AFRICA
}

The Internet has been often presented as an important driver of democratization. A first preliminary observation of these four countries' democratic development points to very different levels of democratization achieved in the last decades, and therefore demonstrates that the impact of technology is greatly mediated by other factors and that technology by itself does not have the power initially attributed by some technological determinist but also rather utopian views (Grossman 1995; Ferdinand 2000, among others).

Through individual and collective histories from Lusophone Africa, and supported by knowledge obtained from interviews, observation, and media analysis, this chapter looks at new online political communication opportunities in countries experiencing democratization processes. It addresses both the role of independent online news media outlets and blogs in environments facing constraints to freedom, and the use of the Internet in citizens' participation and political change.

\title{
Online Political Communication Accounts
}

\section{The Background}

When compared to the rest of the world, the percentage of Internet users in Lusophone African countries, and especially in Angola and Mozambique, is small. Internet access is still very limited outside the main cities, which ends up contributing to accentuating inequalities between regions and social classes. Mozambique is the country with the least people connected to the Internet-only 4.3 percent in 2012. In Angola, the percentage of Internet users was 14.8 percent, and in Sao Tome and Principe it was 20.2 percent in the same year. Cape Verde is the country where the most people have access: 32 percent of citizens were already using the Internet in 2012 (Internet World Stats 2015; Salgado 2015).

Some of the main obstacles to Internet access and use are the high prices and the low quality of most service providers. But the major constraints are still closely related to the poor living conditions that large sections of these countries' populations still face (lack of decent housing with electricity, for example) and low levels of functional, communicational, and media literacies in general. What is demanded of citizens in an information society is much more than knowing how to read and write. The level of competence required to use efficiently the new information and communication technologies involves different types of literacy, such as functional literacy, which refers to comprehension and interpretation skills, and communicational and media literacy, which means that citizens should have the ability to analyze and create different messages in different media genres, and should be able to identify the medium most suited to communicate their ideas (Salgado 2014: 111).

Technology in general, and more recently the Internet in particular, have been pointed out as having the role of facilitators that drive other innovations, democratization, and economic development (Lerner 1958; Mudhai et al. 2009; Nwokeafor and Langmia 2010; Salgado 2012, just to provide some examples related to developing nations). The 2015 United Nations General Assembly's debate recently reinforced the goal of achieving universal access to the Internet by the end of 2020, because, according to this organization, the Internet is directly linked to human development in all of its different facets, including economic and political. This view is not new, and a very similar perspective is shared by the World Bank (2009) in a report that demonstrates that access to affordable and reliable high-speed Internet and mobile communications are central to economic growth and job creation in developing countries. 


\section{S. SALGADO}

Several international organizations have been fundamental in the history of building the Internet in sub-Saharan Africa, particularly in respect to infrastructure and capacity building; however, for the time being, access to technology and information is still extremely differentiated, and these gaps have tended to accentuate the already existing great differences among social and political groups in these societies.

Although the Internet contains in itself the potential for further development, the ways in which it is used and its histories seem to be strongly conditioned by context. Allowing for substantial cross-country differences, there is still a long way to go in the African Portuguesespeaking countries regarding the democratization of Internet access, especially taking into consideration some persisting structural constraints, such as the lack of electricity and telephone lines or broadband access in some remote and rural regions. Indeed, there are strong inequalities in access to the Internet and technologies in general, both between the four countries and within them. Until a few years ago, apart from more wealthy people, the Internet users in these countries were civil servants and other workers in the service sector who had Internet access in their jobs. This gap is clearly reflected in the blogger communities: most bloggers are from the middle and upper classes, and have an academic level considered very high when compared with the rest of the population; there are blogs, for example, by politicians, journalists, academic researchers, historians, and artists (Salgado 2012).

Most usage was also, and still is in many places, confined to the capital city and to major cities. However, even though Internet access is still limited, it has grown in recent years due to the availability of cheaper access to services and the implementation of projects designed to promote Internet access for the general population. Efforts to equip schools, universities, libraries, and other public services with computers and Internet access have increased and, in some cases, small cities and villages were included. Other options are cyber cafés and freeaccess media centers and libraries.

In Angola, a project was put in place to provide all provinces with media libraries, including in the least populated provinces, and to distribute mobile media libraries throughout the country while more definitive structures are not in place. The mobile structures are thus supposed to facilitate the access of the general population to new technologies and allow citizens, including students, to do all kinds of research on the Internet (Angop 2015). In 2015, Angola had six media libraries in Luanda, Benguela, Huambo, Lubango, Saurimo, and Soyo, six mobile media libraries scattered across the country, and plans to establish six more of these structures by the end of the year. The government expects to have at least one of these media centers fully operational in each of Angola's 18 provinces by 2017 (Deutsche Welle 2015).

This project is part of the N'gola Digital program regarding the "Information Society and Technologies of Information and Communication" of the Angolan Ministry of Telecommunications and Information Technologies, which has as its main objectives to provide communities with computers connected to the Internet, and to organize workshops on how to use computers and software at different levels of proficiency. More recently, Movicel, an Angolan mobile phone company, developed a partnership with Facebook, the app "Internet.org", to provide free Internet access to a limited selection of websites related to news, health, employment, weather, and, of course, Facebook (O Pais 2015).

In Cape Verde, the history of the Internet began in 1996 and since then its use has become increasingly affordable to a growing number of people. In 2009, a study by the National Statistics Institute (Instituto Nacional de Estatística (INE)) revealed that in Cape Verde 45.7 percent of the population lived less than 15 minutes away from an Internet connection spot; the percentage was 61.6 percent in the capital city Praia, but in the interior municipality São Salvador do Mundo, only 6.8 percent (Instituto Nacional de Estatística 2009). São Salvador 


\section{HISTORIES OF THE INTERNET IN LUSOPHONE AFRICA}

do Mundo is situated in the central part of Santiago, the same island where the capital city Praia is located. The fact that the Cape Verdean authorities have decided to implement a program to offer free wireless Internet access near the city halls in most cities helped to improve the overall numbers. But also contributing to increasing the number of users and democratizing access is the fact that Cape Verde already has its schools, universities, libraries, and public services in general connected to the Internet.

According to the International Telecommunication Union (ITU), Cape Verde is part of the very small group of African countries with a relatively high proportion of the population online: in 2014, these were Seychelles (50 percent), South Africa (49 percent), Mauritius and Kenya (39 percent), and Cape Verde and Nigeria (38 percent). Cape Verde was not, however, highlighted in this report for its household penetration; only four out of a total of 38 countries in Africa had more than 30 percent of households with Internet access in 2013, and they were: Seychelles (51 percent), Mauritius (45 percent), South Africa (39 percent), and Ghana (32 percent) (ITU 2014: 87-88). Internet penetration levels and the use of new technologies among young people aged 15-24 is around 65 percent in Cape Verde. Finally, access to mobile broadband in Cape Verde and the level of prices of ICTs (the fifth lowest in Africa behind Seychelles, Mauritius, South Africa, and Botswana) were also important drivers of the rapid increase of Internet access in this country (National Communications Authority (Agência Nacional das Comunicações) 2013).

In Sao Tome and Principe the price of having Internet at home was, in 2011, more than 100 euros per month, which is extremely high for a country where 61.7 percent of the population was, in 2009, considered poor (World Bank 2009). The installation of fiber optic in 2012 made better services available, and lowered prices slightly in this country. Companies and international authorities, such as the Chinese government, have been assisting the government in Sao Tome and Principe in opening digital centers and in providing computers with Internet access to libraries throughout the country. This was the case in the Mé-Zóchi district, where a digital center with 30 computers was inaugurated in the village of Trindade, in March 2013, as a joint initiative of the Mé-Zóchi district and the National Institute of Research and Knowledge (Instituto Nacional de Investigação e Conhecimento (INIC)), and funded by the Taiwan Embassy in Sao Tome with US\$60,000. The Mé-Zóchi district has around 15,000 inhabitants, and especially for the underprivileged, this is the only opportunity to acquire digital skills and qualifications. This was not the only project of this kind supported by the Taiwan Embassy: there was also a digital center in the district of Cantagalo, and before Trindade and Cantagalo, the Taiwan Embassy had also supported the library in Principe Island (Jornal Digital 2013). Another noteworthy example is the 'Internet4all' program, implemented in 2004 by the company Bahnhof to train local communities in the use of the Internet.

The price of Internet services is an issue in Mozambique too. According to a report by Beyond Access, ${ }^{3}$ for over 95 percent of its population, Mozambique's Internet services are unaffordable. Its fixed broadband connections are the fourth most expensive in the world, and while mobile services are less expensive, a subscription costs over 65 percent of the average family's income (Beyond Access 2014). Nevertheless, the number of Internet service providers has been growing, which means an increase of companies, institutions, and individuals with Internet access. At the end of the 1990s, the Mozambican National Communications Institute had recorded only one ISP operating in the country, the Eduardo Mondlane University, and in 2014, there were more than 20. But Internet services are heavily concentrated in Maputo, the capital city, and many are reluctant to expand to interior and smaller cities, on the grounds of insufficient demand and unreliable electricity services (Balancing Act 2014). 
The introduction of submarine cables in 2009 and 2010 has made access to cheaper international connectivity possible in Mozambique, but despite this, only a small minority of the population is able to purchase computers and have Internet access at home. Most people use the Internet at their workplaces or in Internet cafés and telecenters. There have been several initiatives by the government and NGOs to provide the country with these infrastructures. For example, in 2006, eight centers were set up to provide access to ICTs in rural communities, through the Social Communication Institute in cooperation with several international organizations as part of a government initiative. More recently, the government has been working with strategic partners to explore the potential of libraries to serve as points of Internet access.

In these countries, the Internet is not systematically controlled, and until now only the Angolan government has tried to regulate access and use of the Internet: in April 2011, it approved in parliament a law that allows authorities to control users and online content, and created a committee to analyze the existing Press Law and to work on the regulation of the Internet. In Mozambique, even though a number of sites remained untouched after criticizing the government, there were reports of government agents monitoring the email accounts of members of opposition political parties (Salgado 2014).

\section{A Young Female Blogger and Opposition Politician in Mozambique}

For her work as a politician, Maria Ivone Soares was one of the nominees for "African emergent personalities" in 2014, distinguished by the news magazine The Africa Report. Maria Ivone Soares has been considered a rising star in the context of opposition politics in Mozambique (see, for instance, Africa Intelligence 2015). For many of her party members and supporters of Mozambican National Resistance (RENAMO), she embodies part of the hopes of accomplishing sustainable changes in Mozambican politics in the near future. She represents a new generation, and embodies a different approach to politics based on dialogue and communication, in which the use of new media has been key.

The Mozambique Liberation Front (FRELIMO) has been ruling Mozambique since independence in 1975 and has won every election after the democratization process started at the beginning of the 1990s. FRELIMO and RENAMO have been the two main parties in the Mozambican party system, but more recently a new influential political force entered the game: RENAMO dissidents created a new political party, Democratic Movement of Mozambique (MDM), which participated in the 2009 election and managed to elect eight of 250 parliamentary deputies.

Mozambique has had regular elections since 1994, but FRELIMO has been consolidating its position the political scene. For instance, in the 2009 election, FRELIMO won with 75 percent in the presidential and legislative elections, while in 2004 the party had fewer votes: 62 percent in the legislative elections and 63.7 percent in the presidential election. While FRELIMO is wining supporters, RENAMO's voting results took the opposite course. In 2004, the party had 29.7 percent in the legislative election and 31.7 percent in the presidential election, and in 2009 its votes decreased to 16.41 percent in the legislative election and 17.68 percent in the presidential election.

The high level of distrust between FRELIMO and RENAMO has been hindering the country's democratization process. On several occasions, RENAMO questioned and refused to accept the election results, and threatened to boycott elections. RENAMO has also been involved in occasional guerrilla attacks and the RENAMO leader, Afonso Dhlakama, has been in hiding for some time in central Mozambique. Aside from these local skirmishes, the 


\section{HISTORIES OF THE INTERNET IN LUSOPHONE AFRICA}

country has been living in peace since the General Peace Agreement was signed in 1992 between RENAMO and FRELIMO, ending a 16-year-long civil war. The tension is nonetheless fully extended to political elites: for example, FRELIMO and RENAMO parliamentary groups frequently reject each other's proposals, regardless of the public value of the proposed policies. This constant lack of agreement has important consequences for political inclusion and the quality of public debate. It also diverts attention from the important issues that concern the population to party quarrels and disputes between political leaders, which end up being the focus of most of the mainstream media coverage.

Maria Ivone Soares is Afonso Dhlakama's niece, but also one of RENAMO's members of parliament, former RENAMO spokesperson, and former leader of the party youth. She has been an active blogger (mariaivonesoares.blogspot.com; rabiscosdasoares.blogspot.com; politic andomoz.blogspot.com), because she sees the potential of this means of communication to raise young people's criticism about the challenges that the country faces in maintaining a multi-party democracy. Maria Ivone Soares is outspoken and pointed to (for instance, by the sociologist Carlos Serra 2007) as an example of courage for assuming her identity in the blogosphere. Only in very few cases do people reveal their identity in the Mozambican blogosphere, and in the case of women, this is even rarer.

Although the Internet is not controlled on a systematic basis, there are reports of bloggers being ordered to cease their activities. Because of this, and also due to the relatively new environment of freedom, some bloggers prefer to maintain anonymity (Salgado 2012). Anonymity encourages the expression of opinions and is an important key driver for political participation in contexts such as this, where citizens are not accustomed to freedom and tolerance. Anonymity is also essential in contexts with constraints to freedom, where there might be persecutions of those who have a different opinion from the authorities or do not share the same views as the majority.

At the same time as the possibility of anonymity is regarded as a driver of political participation, it is also criticized for transforming spaces of participation, such as online news comments and blogs, into slander spaces used to insult opponents and to offend others. The personal attacks and defamation shielded by anonymity that often take place in these online spaces inhibit some citizens from participating in public life, particularly women, and hinder debates in general. Assessing whether anonymous comments and blogs are positive or negative to democratization processes is extremely complicated: although, on one hand, distortion of information and provocations are noticeable in many of these spaces, on the other hand, people tend to reveal more and feel more comfortable about exposing problems than they would be in situations where their face was shown and their name revealed.

Maria Ivone Soares is against anonymity in the blogosphere, but understands that some prefer to write under the protection of nicknames or in secrecy because they fear reprisals. In her blogs, she publishes posts about her position on issues, debates, and political decisions, but also poetry and personal thoughts. She also writes opinion articles regularly, and acknowledges the importance of independent news media in the Mozambican democratization process. According to her, independent news media outlets contribute to diminishing the information deficit regarding Mozambique's real problems and bring new approaches to issues and facts, because independent journalists try to balance news coverage, incorporating different and sometimes contradictory points of view, in addition to the official version of the FRELIMO government (Salgado 2014: 77).

With her political actions and behavior, Maria Ivone Soares intends to be a role model for young people, and girls in particular, inspiring them to speak freely about what is wrong in the country, and giving voice to all those who cannot speak for themselves. One of the reasons 
why she decided to use new media is because, in her view, the multi-party democracy has been threatened in Mozambique, and the challenge is to arouse a posture of critical thought within the younger generations. Given the absence of spaces for opposition politicians to express their alternative ideas, blogs are a privileged space for free expression of opinions.

\section{Activists and Political Prisoners or Troublemakers in Angola?}

Although the Lusophone African blogosphere is awash with posts on politics, human rights issues, and opinions, including criticisms of political authorities, blogs are not a privileged means for collective action and mobilization, as they are mainly used as a means of individual expression. When the objective is to organize protest or support actions, other online tools are usually preferred, such as emails, SMS messages, and social networks.

In Angola, the right to freedom of association, although recognized in the Constitution, is not fully observed in practice. When the people who organize collective popular actions support the president, José Eduardo dos Santos, and the Popular Movement for the Liberation of Angola (MPLA) party and government, there are no obstacles, and they are even assisted by the MPLA party structures. In contrast, when opposition parties or groups and movements that are critical of the president or of the government have tried to initiate actions, they have been quickly repressed by the authorities.

In June 2015, 15 to 17 young democracy activists were arrested and their documents and computers confiscated during a meeting in Luanda where they were gathered to discuss the situation in Angola. They were accused of an attempted coup d'état and of planning to harm the president. After the arrest, the Angolan organization Association for Justice, Peace and Democracy (AJPD) announced that they had been subjected to physical and psychological torture. The non-governmental organization Amnesty International issued a press release condemning what they called "another attempt by the Angolan authorities to intimidate anyone who thinks differently" (Amnesty International 2015). The case brought to mind the events that followed a protest action on 27 May 1977 against the then president, Agostinho Neto, which resulted in the death and disappearance of several people.

This new case involves a group of young educated people who have been very critical of the regime, because, according to them, Angola is a dictatorship, not a democracy. Angola started a democratization process at around the same time as the other Portuguese-speaking African countries in the early 1990s, but given the very low degree of its democratic consolidation and the many setbacks for freedom in general, there has been some ongoing discussion, both in the international press and in scholarly research, on whether the term "democracy" should be applied to the Angolan regime (for instance, Chabal 2002; Chabal and Vidal 2007; Salgado 2014).

The group of activists was composed of nearly 20 people (some went missing immediately after the meeting), including: rapper Luaty Beirão, who went on a hunger strike for 36 days to protest against these imprisonments; Manuel Nito Alves, a very young activist who was imprisoned for a couple of months in 2013 for wearing an anti-President dos Santos T-shirt, and who adopted the name of one of the leading voices (Nito Alves) against the former president, Agostinho Neto, in 1977; and university professor Nuno Dala. They were arrested and accused by the Criminal Investigation Services of the Interior Ministry of "preparing actions with the intention of changing the country's order and public security" (Público 2015a).

The so-called Angolan Revolutionary Movement was inspired by the Arab Spring movements and mainly calls into question the permanence of President José Eduardo dos Santos, who has been in power since 1979 and is one of the longest ruling leaders in Africa. 


\section{HISTORIES OF THE INTERNET IN LUSOPHONE AFRICA}

They also argued for the observance of human rights and demanded improvements in public policies, as well as the end of corruption and poor governance. More recently, demonstrations were organized to demand an end to police violence against demonstrators.

The group was behind the organization of several demonstrations against President José Eduardo dos Santos, and its members were very active in the growing online protests, noticeably in different social networks and discussion forums. Opposition political parties and political and social movements not aligned with the MPLA government do not have access to mainstream media to convey their messages, and if they appear in the news, they are framed negatively as delinquents and troublemakers. Regarding the Angolan media system, the stateowned media are completely controlled by the MPLA, and private ownership does not necessarily mean being independent of the MPLA government, President José Eduardo dos Santos, and his close supporters. In recent years there has been an important attempt by the MPLA political elite to further control the media system, through the purchase and launch of private news media outlets. Such a strategy allows conveying an external image of plurality in the media and content suppliers, while completely filling the space allowed to private initiative, to prevent the actual alternative voices (independent from the MPLA) of getting access to their own spaces of expression. This should be interpreted as a form of constraining dissent and any contestation (Salgado 2014: 67).

In fact, the Internet and online media have become powerful tools to gain sympathizers and mobilize more supporters for political and other causes, especially when there are no alternatives within the mainstream media system. But they are also a means for regimes to control opponents and follow their activities closely. In fact, Evgeny Morozov (2011) has recently insisted on the idea, somewhat against the current, that Internet freedom is, in most cases, an illusion. He has drawn attention to evidence that confirms that the Internet can be used as an instrument by authoritarian regimes to maintain their power and to oppress citizens even more: in several places, dictators have been using the Internet to launch misinformation campaigns and have been pursuing dissidents through their online trails.

This group of Angolan political activists was closely monitored, and all their online tracks apparently followed by the regime to prevent new popular demonstrations and to control their actions in general. Their social network accounts were full of references to demonstrations and to the need to organize "strong movements and eventually evolve to political party interventions". Words and phrases such as "revolution", "fight against the regime", "end corruption", "end censorship" are common. In addition to the online surveillance, these young activists have also complained about the presence of "moles" (people working for the secret services) in some of their meetings.

Between 2011 and 2013, a few demonstrations were organized in Luanda by these activists, but the frequency of these events was dramatically reduced-not because of a lack of mobilization, but simply because the authorities were able to prevent them from happening. In the first events, the authorities allowed the demonstrations to start, but soon after, the police force intervened to identify and arrest some of the demonstrators, dispersing the remainder. More recently, the protests have been put down by the security forces even before they start, and due to this sometimes violent repression, many citizens are afraid of joining the protests (Público 2015b).

In Angola, following the events in Tunisia and Egypt, in March 2011, the protest began on the Internet when emails and an anonymous website (http://revolucaoangolana.webs.com) announced the "New Revolution of the Angolan people", calling on people to demonstrate against the MPLA and the president. The MPLA government, not willing to tolerate any comparisons between Angola and the northern African countries, reacted strongly, ensuring 
that public order would be maintained at any cost, despite the fact that the Angolan Constitution grants all citizens the right to demonstrate peacefully. In March 2011, and in several other demonstrations and demonstration attempts that followed (for example, in July 2011, March 2012, December 2012, March 2013, June 2013), the authorities responded with a heavy police presence. On some of these occasions, counter-demonstrations in favor of the government were organized to take place at the same time.

It is thus not surprising that the Angolan government has also prepared new legislation designed to control and restrict the online environment. In 2011, the National Assembly approved a bill criminalizing the use of the Internet and mobile phones to send any type of information without the prior written consent of everybody mentioned in its contents. This new law, presented as a data protection measure, establishes imprisonment time and allows the security forces to conduct searches and confiscate data and documents without a court order. It was also carefully designed to prevent protests initiated and coordinated through the Internet from happening.

In an effort to prevent online activism, there were also attempts to block social networks in Cameroon, Uganda, and Swaziland; however, Angola was at the forefront with regard to drafting repressive legislation. This attempt to regulate online activity comes in line with the MPLA government's restrictive posture towards the media in general. It also shows that, although Internet penetration levels are not particularly high, the number of people with access is already enough to shake the political situation slightly. Until a few years ago, almost no one dared to criticize the president in public; however, more recently the Internet and the pro-democracy and freedom initiatives have encouraged more people to show their discontent.

\section{Online Political Activism in Cape Verde: Young People, New Media}

In Cape Verde at the beginning of 2015, a similar group of young people decided to join forces to engage in politics actively as a civic movement. They have subsequently been successful in organizing demonstrations and mobilizing the Cape Verdean youth, among others. It all started with the deep disappointment among young citizens about their job prospects, the direction the country was going, and the behavior of the ruling elites in general.

The civic action movement Movimento de Acção Cívica, MAC\#114, is a political, yet non-partisan, movement, founded by a group of young jobless graduates, young professionals, and students with the objectives of involving young people in the political decisions that affect their lives and of making the youth more aware of their rights. The group, founded and led by 33-year-old sociology graduate and farmer Rony Moreira, has opted for a decentralized leadership model present throughout the main Cape Verde cities, and wants to function as a "pressure group" committed to raising civic awareness among young people and the underprivileged in general.

Rony Moreira was formerly affiliated with the African Party for the Independence of Cape Verde (PAICV), and a youth leader who was expelled for criticizing some of the party leaders' positions, which in his opinion were not following the ideals of a left-wing party committed to promoting equality of rights and opportunities for all and to allocating the country's public resources in a balanced way. Some of the other names involved in the movement are: Adilson Correia, from Assomada (a city in the interior of Santiago island), who is 29 years old and an electronics teacher; Vacilísio Gomes, 28 years old, a political science and international relations graduate student at the University of Mindelo, in São Vicente island; and Jassy Sousa, an international relations graduate from Sal island. They share the goal of mobilizing Cape 


\section{HISTORIES OF THE INTERNET IN LUSOPHONE AFRICA}

Verdean public opinion so as to debate issues that concern the population, such as unemployment, insecurity, poverty, injustice, and inequality (interview with MAC\#114 members, by newspaper A Semana).

Cape Verde is usually pointed out as an example in Africa of the successful implementation of a democratic regime, because the development of democratic institutions has been sustainable and long-lasting. With very few resources and a very dry climate, Cape Verde is considered a poor country. Successive governments in the democratization period have tried to circumvent some of these difficulties by making important investments in human resources formation. Cape Verde is currently one of the few sub-Saharan African countries with a medium human development index (in the same group as South Africa, Botswana, and Namibia), ${ }^{4}$ and is pointed to as one of the most free countries, both for journalists and the general population. Despite the overall good indicators in terms of both human development and democratic consolidation, Cape Verde currently faces important challenges, such as increasing levels of criminality across the country, mainly related to drug and alcohol abuse and growing youth unemployment. The country's strategic location along drug-trafficking routes is another major concern, given that this could mean a rapid increase in criminality and insecurity in general, influencing negatively both the unemployed youth and the rising tourism sector, one of the most important economic sectors in the country.

Despite successful democratic consolidation, some issues regarding a strong political bipolarization between the two main parties, PAICV and Movement for Democracy (MpD), and the obstacles that fringe political actors face to be included in debates and to be covered by the mainstream media, have been raised. In addition, the existence of corruption in the form of vote buying represents an institutionalized strategy of electoral campaigning. There is political and party competition, but translated into strong bipolarization between the two main political parties that have been alternating in power. Small political forces complain about the political bipolarization that prevents them from achieving better results in elections and denounce the use of public resources by the two main political parties. Also lacking in Cape Verde is the deepening of a culture of criticism, in which the population feels less apprehensive about questioning the government's decisions and action, as well as structures that mobilize and organize all those citizens who are unhappy with the current state of affairs and the way governments, parties, and members of parliament have been conducting politics.

What is at stake for MAC\#114 is the right to equal opportunities and social justicebasically, the idea that the distribution of opportunities, wealth, and privileges needs to be fair in Cape Verde. So it is no coincidence that the trigger that became their first great battle and propelled the first street protests was the approval of new regulation regarding the Statute of Political Position Holders in Parliament. The new proposed statute included more privileges, such as a 65 percent salary increase considered immoral by these activists, given the situation in which most of the people live. They were also against the fact that members of parliament are not obliged to restrict their employment, which opens the door to situations of intermingling of business, political, and even media interests.

The "114" in the name of the movement is related to article 114 of the Rules of Procedure at the National Assembly. It is invoked whenever an MP wants to defend their honor and was included in the name of the movement because these activists want to restore the honor of the unemployed and the underprivileged Cape Verdean citizens. Although it is a movement clearly identified with Cape Verdean youth, its support structure has widened quickly, and it now includes people from different social, religious, and political sectors of society. 
Probably inspired by other political movements, such as the Indignados in Portugal and Spain, MAC\#114 stands for a participatory model of democracy, a more inclusive configuration of power that takes into account different interests in the policy-making process, with citizens' political involvement going beyond their vote in elections. MAC\#114 also criticizes the type of "clientelist democracy" that both PAICV and MpD have supposedly been implementing, in which social mobility and job opportunities are related to belonging to these parties. Basically, the ideas of participation, equitable distribution of resources, social justice, and equal opportunities drive this political movement, and are supported by the objectives of raising citizens' awareness about their rights and democratic ideals in general, while providing them with the necessary structures of mobilization as tools to affect changes in politics.

In Cape Verde, the media system is an accurate picture of the bipolarization of the political system. The two political parties that have alternated in government (PAICV and $\mathrm{MpD}$ ), have at one time or another controlled the broadcasting sector (state-owned television and radio stations), while the weekly private newspapers are divided in support of these two parties. In terms of news content, the newspapers' political orientation is noticeable in opinions and commentaries, but also in how information is selected and presented. For instance, the smaller political forces often complain about the difficulties in getting their messages across in the mainstream media (Salgado 2014: 168). The press's monitoring role is therefore somehow compromised, and at the same time, the two main parties' institutional communication is usually very strong.

With no access to the mainstream media agenda, MAC\#114 has taken to social networks, especially Facebook, which has become its most important communication tool when it comes to both informing about the movement's objectives and mobilizing people for collective action. Use of the Internet as a means of influence, and as a tool to express opinions, is not new in Cape Verde. Since its use started to expand, the Internet has been used by different political and social actors, first through blogs, and then increasingly through social networking websites, to read and comment on the news, and to publish blogs on different topics. MAC\#114 is the first example of systematic use of the Internet for citizens' mobilization.

\section{An Online Journalist in Sao Tome and Principe}

The Santomean journalist Abel Veiga has made the Internet his working environment. Because he launched the first online paper in 2000, he is considered one of the "fathers of digital journalism" in the archipelago. Téla Non was not only the first online paper in Sao Tome and Principe, but it was also the only daily newspaper in the country. Téla Non was also the first to allow readers' comments and to promote discussions about news and issues in general, and is one of the very few independent media outlets operating in the country.

Sao Tome and Principe's media system reflects the characteristics of a very small and very poor country, with extremely high newspaper prices for the general population, a very small advertising market and extremely low newspaper-reading rates. Independent news media are rare in Sao Tome and Principe. In addition to the high level of politicization of the news media, two other reasons explain this: severe economic difficulties, and widespread selfcensorship among the small journalistic community (the Union of Journalists estimates that the number of journalists was around 100 in 2012).

When compared with online newspapers in other Portuguese-speaking African countries, Téla Non is indeed one of the online papers with more comments from readers. They are 


\section{HISTORIES OF THE INTERNET IN LUSOPHONE AFRICA}

given the opportunity to comment on the issues raised by the news stories, but readers also use the space to request and exchange different kinds of information among themselves, making this website an actual forum for citizens. Although on a smaller scale when compared with consolidated democracies and more developed countries, the immediate result of these different online publications is that more information and new perspectives on issues, actors, and events are available, including foreign experiences and foreign evaluations of national experiences (Salgado 2014).

Téla Non is widely read by politicians, journalists, students, civil servants, and the remaining small fraction of the population with Internet access (the price of having Internet access at home was around 100 euros per month in 2011), but most of its readers are located abroad. These include business people with interests in Sao Tome and Principe, and the diaspora community that is a very important audience for Téla Non, especially from countries such as Portugal, Brazil, Angola, Cape Verde, the United Kingdom, France, and the United States of America. In fact, the number of average monthly website users from Portugal was three times higher than Santomean users in 2012.

In addition to the important international exposure of this online newspaper, Téla Non's content also reaches parts of the population in Sao Tome and Principe without Internet access through other news media outlets and such means as friends, colleagues, and word of mouth. So, despite major limitations in access to the Internet for a large part of the population, content published online can reach wider audiences through other means of communication (some television and radio shows present summaries of the online press headlines), or even through interpersonal communication. Important and controversial news stories are often printed and distributed, and, for instance, in the city of Sao Tome, some taxi drivers print some of Téla Non's news stories for their clients to read during the ride. Due to scarce human resources some private radio stations feed their news reports with Téla Non's news content, functioning in this way as "resonance boxes".

This is all the more important as Téla Non has a vital role in setting the media agenda, because it covers some of the events and issues that the state-owned media prefer to ignore. Abel Veiga sees online media, both newspapers and blogs, as extremely important for improving the quality and the plurality of information in Sao Tome and Principe. The Santomean online informational environment has contributed to offer different-and sometimes contradictory - versions of issues and events, and it has also stimulated competition between news media outlets, which has contributed to improve the overall quality of news content. All of this has had a positive influence on both freedom of information and freedom of expression in the country.

In the Santomean context, Abel Veiga has a bold vision of the role of the news media. For him, democracy means open debate and plurality of views, so only with the existence of such conditions can any country be considered democratic. The Constitution has guaranteed freedom of expression since 1991 and freedom of the press is also ensured by law. However, there are constraints that limit the levels of freedom in the country: "Journalists are often intimidated, which results in high levels of self-censorship. There are no beatings, but journalists deal with threats, professional retaliations, judicial processes" (interview conducted by the author of this chapter on 29 June 2011; for more information, see Salgado 2014: 93-108).

Those in power are accustomed to control the media in Sao Tome and Principe. The state-owned television and radio stations are instruments used by the ruling parties, and most of the private news media are also controlled indirectly. There are very few independent news media outlets and there have been many different attempts to silence their voices or to 
persuade them to support the party in power. Its international impact makes Téla Non particularly interesting for politicians. In addition, Téla Non has always had a critical approach that arises from its stated mission of monitoring the conduct of elected officials and politicians in general. This objective is nevertheless often perceived by politicians as a hidden agenda to overthrow governments and political leaders. Abel Veiga believes that Téla Non's open nature, promoting participation and debates, is essential to its mission, and argues that the objective is to act on behalf of the population, showing and discussing what is wrong, not to overthrow any government.

Political instability is an issue in Sao Tome and Principe. Since its transition to a multiparty system in 1991, this country has had many more governments and prime ministers than elections: in 20 years there were 19 prime ministers, and no government lasted a full parliamentary term. This is one of the effects of strong disagreements between political parties and even stronger personal (more than ideological) divergences among the political elites (Salgado 2014: 83). The fact that Sao Tome and Principe is a very small country does not help, because most people know each other personally. There are many grudges accumulated over the years, and relations between politicians and the independent news media are often conflicting.

The constraints to journalistic work are worse in the case of the independent media. Their access to political sources is very limited, because governments prefer to release information through the state-owned media to ensure control of the actual news content, and in some cases, the political elites even order information blackouts against the independent media. The argument used is that the media need to speak with a single voice to prevent political instability, and that too much plurality and debate would, in fact, be harmful for democracy. Abel Veiga completely disagrees with these arguments, and sees the politicians as the only ones responsible for political instability. In his view, plurality is an extremely important value, and online newspapers and blogs have been contributing to improved freedom in Sao Tome and Principe, and promoting debate on issues. Many of these publications have been developed outside the political elites' control, which makes them particularly important in a democracy-building context.

\section{Prospects and Different Democratic Developments}

These histories of the Internet illustrate the state of democratic development of Mozambique, Angola, Cape Verde, and Sao Tome and Principe. These are histories of individuals and groups in respect to their ideals and goals, and their use of the Internet, but these are also accounts of freedom of the press, plurality, freedom of expression, freedom of association, and of struggles for equal rights and social justice.

The Internet has enabled alternative power dynamics, which in these cases have more or less conflicted and challenged the status quo. These actors, movements, and publications emerged and flourished in their national contexts due to the Internet. They represent new ways of mediating political communication and power in contexts where the Internet is more than just a new media vehicle for political information. Enhancing creative practices and shaping interplays, it provides opportunities to go beyond established discourses, and contributes to creating new power configurations. However, the impact on democracy is not always the same: in some cases, the Internet has forced some openness, while in others it has caused further repression. It is, thus, a mistake to assume that a country is only going to be more democratic and free because of the Internet. 


\section{HISTORIES OF THE INTERNET IN LUSOPHONE AFRICA}

Some of the most democratizing features of the Internet are related to the democratization of information: not only has the Internet the potential to multiply information producers, but it can also facilitate access to more diverse sources of information. The Internet therefore offers the potential for decentralized information production and distribution, allowing more ideas and opinions to circulate, which in itself is a valuable tool in democracy. The Internet also has the potential to boost citizen mobilization and participation. How the Internet's potential is explored and how the available information is used varies according to context.

The Internet opens up new possibilities that are the result of technological innovation and development, but the ways in which it is used are strongly shaped by the surrounding environment. In Cape Verde, it has allowed activists to mobilize the population and influence policy making, but in Angola it was used as a surveillance weapon against the pro-democracy activists. In Mozambique, the Internet serves as means of communication for an opposition politician, and in Sao Tome and Principe as a medium for an independent press. Some of the Internet's most important distinctive features—interconnectivity, immediacy, interactivity, anonymity, the possibility of becoming "viral" — can be useful to both dictators and democrats. The Internet is shaped by actors according to their histories, goals, and ability to use it.

\section{Notes}

1. This chapter is part of a larger research project funded by the Portuguese Foundation for Science and Technology and developed between 2008 and 2014, which included extensive fieldwork and interviews with local actors.

2. Guinea Bissau is not included in this study.

3. Beyond Access is an initiative of IREX, an international non-profit organization with support from the Bill and Melinda Gates Foundation.

4. The human development index is one of the United Nations Development Programme's tools to assess the overall quality of life of human beings. It is a statistic derived from combined indices on life expectancy, education, and income in each country, and is used to compare and rank countries. Countries are usually divided into three groups: high, medium, and low human development. Most of the sub-Saharan African countries are in the "low human development" group.

\section{References}

Africa Intelligence (2015) “Maria Ivone Soares, Renamo's star”, Africa Intelligence, 1 October, available at: www.africaintelligence.com/ION/who-s-who/2015/10/01/maria-ivone-soares-renamo-s-star,108050284-ART

Amnesty International (2015) “Ativistas Detidos em Angola têm de ser Imediatamente Libertos", 22 June, Amnesty International Portugal, available at: www.amnistia-internacional.pt/index.php?option $=$ com_content\&view $=$ article\&id=2163:2015-06-22-19-23-52\&catid=43: angola\&Itemid $=109$

Angop (2015) "Bié: Província Ganha Mediateca Móvel", Angop: Agência Angola Press, 22 April, available at: www.portalangop.co.ao/angola/pt_pt/noticias/lazer-e-cultura/2015/3/17/Bie-Provincia-ganha-mediatecamovel,099252ba-f1 f8-414e-a908-7e533926d6d0.html (accessed 28 October 2015).

A Semana (2015) "Mac\#114, o Movimento que fez 'Tremer' a Classe Política Cabo-Verdiana”, A Semana, 15 May. Balancing Act (2014) "Internet Access on the Increase in Mozambique", Telecoms, Internet and Broadcast in Africa, 329, available at: www.balancingact-africa.com/news/en/issue-no-329/Internet/Internet-access-on-t/en (accessed 29 October 2015).

Beyond Access (2014) "Boosting Access to Affordable Internet in Mozambique", Beyond Access, available at: http://beyondaccess.net/2014/07/11/affordable-Internet-mozambique/ (accessed 29 October 2015).

Chabal, P. (2002) A History of Postcolonial Lusophone Africa, Bloomington, IN: Indiana University Press.

Chabal, P., and Vidal, N. (eds) (2007) Angola: The Weight of History, London: Hurst Publishers.

Deutsche Welle (2015) “Acesso 'Sem Filtros' à Internet em Angola”, Deutsche Welle, 3 June, available at: www.dw. $\mathrm{com} / \mathrm{pt} /$ acesso-sem-filtros-à-Internet-em-angola/a-18495315?maca=bra-cb_po_globalvoices-14551-xml-mrs (accessed 28 October 2015).

Ferdinand, P. (ed.) (2000) The Internet, Democracy and Democratization, London: Frank Cass.

Grossman, L. K. (1995) The Electronic Republic: Reshaping Democracy in the Information Age, New York: Viking Press. 


\section{S. SALGADO}

Huntington, S. (1991) The Third Wave: Democratization in the Late Twentieth Century, Norman, OK: University of Oklahoma Press.

Instituto Nacional de Estatística (2009) Questionário Unificado de Indicadores Básicos de Bem-Estar (Questionnaire on Well-Being Indicators), Praia: Instituto Nacional de Estatística.

International Telecommunication Union (ITU) (2014) "Measuring the Information Society Report", International Telecommunication Union, Geneva, available at: www.itu.int/en/ITUD/Statistics/Documents/publications/mis 2014/MIS2014_without_Annex_4.pdf (accessed 29 October 2015).

Internet World Stats (2015) "Internet Usage Statistics for Africa", Internet World Stats, available at: www.Internet worldstats.com/stats1.htm (accessed 29 April 2015).

Jornal Digital (2013) “São Tomé e Príncipe: Trindade já Dispõe de um Centro Digital”, Jornal Digital, 4 April, available at: www.jornaldigital.com/noticias.php?noticia $=35764$ (accessed June 2013).

Lerner, D. (1958) The Passing of Traditional Society: Modernizing the Middle East, New York: Free Press.

Morozov, E. (2011) The Net Delusion: The Dark Side of Internet Freedom, New York: PublicAffairs.

Mudhai, O. F., Tettey, W. J., and Banda, F. (eds) (2009) African Media and the Digital Public Sphere, New York: Palgrave Macmillan.

National Communications Authority (2013) "Cabo Verde Sobe Cinco Posições no Ranking Global da UIT Soobre índice de Desenvolvimento das TIC", National Communications Authority of Cape Verde, available at: www.anac.cv/index.php?option=com_content\&view=article\&id=323 (accessed 29 October 2015).

Nwokeafor, C. U., and Langmia, K. (eds) (2010) Media and Technology in Emerging African Democracies, Lanham, MD: University Press of America.

O País (2015) "Internet Grátis Chega a Angola", 29 June, available at: http://opais.co.ao/Internet-gratis-chegaangola/ (accessed 29 October 2015).

Público (2015a) “Activistas Detidos Numa Casa em Luanda por Perturbação da Ordem Pública”, 22 June, available at: www.publico.pt/mundo/noticia/activistas-detidos-numa-casa-em-luanda-por-perturbacao-da-ordem-publica1699733?page $=-1$

Público (2015b) "A Repressão Está Agora a Chegar a um Nível Diferente em Angola”, Público, 23 June, available at: www.publico.pt/mundo/noticia/a-repressao-esta-agora-a-chegar-a-um-nivel-diferente-em-angola-1699860? page $=-1$

Salgado, S. (2012) "The Web in African Countries: Exploring the Possible Influences of the Internet in the Democratization Processes", Information, Communication \& Society, 15(9): 1373-1389.

Salgado, S. (2014) The Internet and Democracy Building in Lusophone African Countries, Surrey: Ashgate.

Salgado, S. (2015) "Political Participation, Alternative Media and Citizen Journalism in Lusophone Africa", in B. Mutsvairo (ed.), A Connected Continent: Perspectives on Participatory Politics and Citizen Journalism in a Networked Africa, Hampshire: Palgrave, pp. 187-201.

Serra, C. (2007) "Um Caso Inédito: Maria Ivone Soares" (A Unique Case: Maria Ivone Soares), Diário de um Sociólogo (Diary of a Sociologist), 19 September, available at: http://oficinadesociologia.blogspot.com.au/2007/09/ um-caso-indito-maria-ivone-soares.html

World Bank (2009) "IC4D, Information and Communications for Development 2009: Extending Reach and Increasing Impact", Global Information and Communications Technology Department of the World Bank and IFC, available at: http://web.worldbank.org/ (accessed 3 September 2015). 